\title{
Understanding Continuous Participation of Customers in Online Co-innovation Community
}

\author{
Jing $\mathrm{Li}^{*}$, Thepphavong Liphong, Yan Qin, Qiaolun Gu \\ School of Economic and Management, Tianjin University of Technology and Education, Tianjin 300222, China
}

Corresponding Author Email: guqiaolun@tute.edu.cn

https://doi.org/10.18280/ijsdp.150617

Received: 18 March 2020

Accepted: 3 June 2020

\section{Keywords:}

customer, co-innovation, online community, continuous participation

\begin{abstract}
Online co-innovation community is booming in the age of the Internet. After accessing the community, customers can share their ideas and opinions, and work together with brand designers. The initial adoption of participation in co-innovation community has been discussed by many scholars. However, there is little report on the post-adoptive intentions and behaviors of customers. To make up for the gap, this paper extends the technology acceptance model (TAM) with two dimensions, namely, community atmosphere and prior experience (including perceived positive feedback and degree of participation), and relies on the extended model to predict the customer attitude and intention to/for continuous participation in Xiaomi online innovation community. The results show that the attitude to continuous participation is a good predictor of the intention for continuous participation; community atmosphere and perceived usefulness have a significant effect on the attitude to continuous participation; perceived ease of use does not have a significant effect on the attitude to continuous participation; both perceived usefulness and perceived ease of use are affected by perceived positive feedback; the degree of participation has a great impact on perceived ease of use, but not on perceived usefulness. The research findings lay a solid foundation for further research into the continuous behaviors in online co-innovation communities.
\end{abstract}

\section{INTRODUCTION}

The value of co-innovation is growing in the field of business marketing. Considering the important impact of coinnovation on the creative design of popular products/services, several enterprises have established co-innovation spaces, allowing customers to contribute and discuss ideas, suggest solutions, and participate in product development [1]. The boom of Internet communication technology has given rise to online co-innovation platforms, which bring multiple benefits to enterprises: customer ideas could be integrated through coinnovation activities on these platforms; innovative ideas could be acquired at a faster speed and a lower cost; external innovators could be leveraged to lower the cost of research and development (R\&D) and boost market acceptance of products/services [2].

In fact, many famous enterprises have utilized online coinnovation platforms. For instance, Lego System A/S, a Danish toy production company, created a co-innovation site (ideas.lego.com) in 2004, encouraging customers to join the invention of their products. This co-innovation site, as an online co-innovation platform, asks Lego fans to post and vote for their designs of new playsets. Any design receiving over 10,000 votes will be considered for production by Lego. The designer will be awarded with $1 \%$ of the net sales and a monetary incentive for participation. Similarly, IKEA, a global home furnishings retailer, launched its co-innovation site (productideas.co-createikea.com). On this site, any customer who is curious and passionate about trends and details of product design can share their ideas of new products with IKEA designers. In this way, IKEA could accurately grasp the important aspects of product design, and provide suitable solutions to customers around the world.

With the growing acceptance of open innovation and value co-creation, a novel type of online virtual community, namely, online co-innovation community, has emerged by virtue of Internet communication technology. This community is generally created and operated by the enterprise by means of Web 2.0, providing customers with the opportunity to cooperate with designers in the design, development, and promotion of new products/services. In online co-innovation community, customers can get involved in the production process of the enterprise, in addition to the social behaviors (e.g. small talks, making friends, and sharing interests) supported by traditional online communities. However, there is little report on customer participation in co-innovation community, which focuses on product/service development and management. Most scholars have emphasized on traditional online communities operated and managed by third-party platforms or non-profit organizations, and examined user participation from the perspective of a single social behavior. Only a few scholars have clarified the motives of customers to participate in product/service development. But continuous participation, i.e. the participation in the long term, has not attracted much attention [3].

Evidence on co-innovation community indicates that customers often have a high willingness to participate in product/service development, but their participation becomes less frequent, as their enthusiasm dwindles over time [4-6]. Bettoni et al. [7] observed that several online co-innovation communities failed soon after launch, for failure to keep customers engaged in the long run; most customers who are 
passionate about co-innovation ceased participating in less than a month; very few of them participated continuously for over six months [8]. For many enterprises, pursuing the coinnovation with customers is merely a gesture to embrace the trendy concept of customer relationship management. Actually, it is critical for them to build an online innovation platform that facilitates and maintains customer participation in the value creation process. As the operator of online coinnovation community, the enterprise must fully understand the continuous participation of customers.

This paper attempts to disclose the mechanism behind customer continuous participation in online co-innovation. Firstly, an online survey was carried out on Xiaomi online coinnovation community. After that, the relevant hypotheses were tested through structural equation modeling (SEM), and the influencing factors of continuous participation in the community were discussed in details. The research results enrich the practices and theories about online co-innovation between customers and enterprises.

\section{LITERATURE REVIEW}

\subsection{Online co-innovation community}

As mentioned before, online co-innovation community is a novel type of online virtual community, inspired by the concepts of open innovation and value co-creation. The emergence of online co-innovation community is attributable to the proliferation of Internet communication technology. By building an online co-innovation community, the enterprise offers a chance for customers to partake in the design, development, and promotion of new products/services.

The online co-innovation community have multiple functional modules, including but not limited to product introduction, frequently asked questions (FAQs), message board, email, online survey, virtual community, customization, customer design, and virtual laboratory. Each module allows a unique degree of customer participation. Compared with traditional online virtual community, online co-innovation community greatly bolster customer involvement in the production process.

With online co-innovation community, the enterprise aims to gather customer needs and requirements for products/services, and integrate them in the design, development, and promotion of new products/services [9]. Through co-innovation, customers contribute their creative ideas and advices about product/service development, and even directly cooperate with the enterprise in developing new products/services. However, the development of products/services requires a good command of professional knowledge and a wealth of relevant experience, which are not available in a general user [10]. Figure 1 clarifies the working principle of online co-innovation community.

\subsection{Technology acceptance model (TAM)}

Proposed by Davis in 1986, the TAM is the most widely used model to predict whether users will accept and use the information system as shown in Figure 2. The prediction accuracy of the TAM is about $40 \%[11,12]$. According to the classical TAM, the two most important constructs that affect user attitude towards technology are perceived usefulness and perceived ease of use. The former is the degree that a user believes that he/she can improve job performance by using a particular system, and the latter is the degree that a user believes that a system is easy to use. The user takes a positive attitude towards the system that he/she believes to be useful or easy to use. In addition, the perceived ease of use reinforces the perceived usefulness.

The TAM provides a general explanation to the various usage behaviors of specific information systems. Of course, the model needs to be improved against the research context, because external variables are closely related to the specific context. According to the meta-analysis of Legris et al., external variables in different research show an unstructured state, owing to the differences between research contexts [13].

Considering the technology features of online co-innovation community, this paper combines the TAM with external variables to understand the continuous participation in online co-innovation community.



Figure 1. The working principle of online co-innovation community 


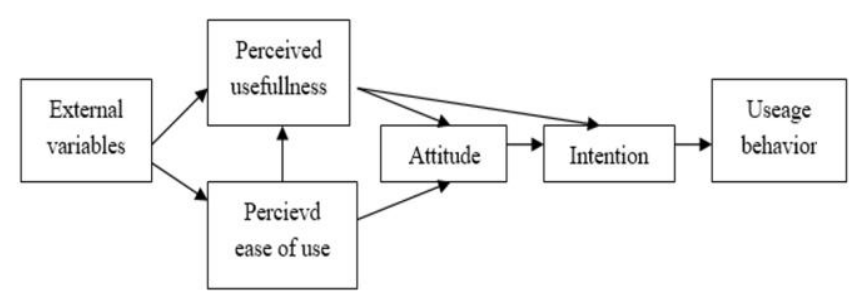

Figure 2. The structure of the TAM

\subsection{Continuous participation}

Continuous participation is defined as the regular interaction and information sharing in a specific place over a period [14]. The subjects of continuous participation are usually satisfied with and passionate about their current product/service [15]. In the online co-innovation community, customer continuous participation is composed of a series of post-adoptive intentions and behaviors, which are the results of the prior experience of customers, that is, previous participations in the community.

The reasons of participation in online co-innovation have been tested empirically over the years. Many factors have been found to affect customer intentions and behaviors of participation, namely, social identity [16], informational benefits [17], commitment [18], enjoyment [19], relational benefits (e.g. sense of belonging) [20], and reputational benefits [19]. Nevertheless, there is not yet a clear illustration of what affects the continuous participation in online coinnovation community.

Based on expectation disconfirmation theory, the information system (IS) continuity model holds that users are able to compare their initial expectations with actual experiences in the post adoption stage [21]. Oliver [22] pioneered the adaptation-level theory on customer satisfaction, pointing out that expectations serve as a reference frame for the cognitive comparison between pre-purchase expectation and the perceived product/service performance. If the perceived performance exceeds expectation (positive disconfirmation), the customer will be satisfied; if the perceived performance falls short of expectation (negative disconfirmation), the customer will be dissatisfied. To maintain the current relationships and facilitate future relationships, it is important to the customer to have a satisfactory purchase experience [23].

Liang et al. [24] suggested that the information sharing among customers is greatly affected by organization efforts (e.g. organizational support), the reward system, and community atmosphere, and directly propelled by individual cognition, and interpersonal interaction. Individual cognition refers to the perceived benefits and commitment, while interpersonal interaction refers to the individual actions in dyadic relations, covering such factors as social interactions with other communities, trust among members, and social network centrality [25, 26]. Lu and Hsiao [27] argued that customer intention for continuous information sharing online hinges on their expectation of outcomes, e.g. the fulfilment of personal needs, and the reward from their actions. Zhang et al. [28] explored the customer intention for continuous participation in online question and answer (Q\&A) community, from the perspectives of community response and member role.

\section{MODELLING AND HYPOTHESES}

Under the framework of the TAM (Figure 3), this paper incorporates prior experience and community atmosphere as factors affecting customer intention for continuous participation in online co-innovation community, drawing on the expectation disconfirmation theory and the relevant findings in literature.

\subsection{Prior experience}

Prior experience, that is, the past behaviors, makes knowledge more accessible in memory, and directly bears on user behavior $[29,30]$. In the co-innovation community, the prior experience of a customer covers many items. The positive items, a.k.a. perceived positive feedback, include receiving reward, adoption of idea/design, getting employed in the enterprise, and gaining followers. Apart from these, the prior experience also involves the degree of participation.

Expectation disconfirmation theory suggests that, before making the decision on continuous participation, people tend to compare their experience and feelings of initial participation with their expectations. Chiu et al. [31] stated that prior experience is a predictor of the intention for continuous participation. As mentioned above, the customer might be satisfied or dissatisfied with his/her prior experience of information technology (IT) usage. Here, the customer prior experience is taken as an important impactor of the continuous participation in online co-innovation community.



Figure 3. The research framework 


\subsubsection{Perceived positive feedback}

For a customer of online co-innovation community, the motive of continuous participation will grow when he/she receives positive feedback after posting an idea or comment [32]. The perceived positive feedback is not necessarily monetary or physical. For often, the feedback is largely psychological, including the recognition and sense of fulfilment, as his/her idea is accepted by the enterprise or deemed as helpful by other members in the community. Taking the Xiaomi online co-innovation community for example, important customer behaviors like sharing new ideas, reporting problems, and relying to other members will win the customer a medal in his/her profile, so that everyone can know how much he/she has contributed to the community.

Faullant and Dolfus [32] demonstrated that customers will be more motivated to remain active, after receiving positive feedback like likes and comments on their posts, even if the comments are not entirely positive. Rice et al. [33] verified the effect of social support on perceived value and continuous participation in the social media: the customer-customer interaction has greater impact on customer motivation than customer-enterprise interaction. Focusing on continuous

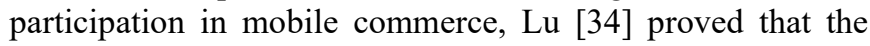
customer-customer interaction significantly affects the perceived usefulness and ease of use. To sum up, the perceived positive feedback is related to the perceived usefulness of previous participation, as well as the decision on continuous participation. On this basis, the following hypotheses were put forward:

H1a. Perceived positive feedback has a positive influence on perceived usefulness towards online co-innovation community.

H1b. Perceived positive feedback has a positive influence on perceived ease of use towards online co-innovation community.

\subsubsection{Degree of participation}

The degree of participation stands for how much a customer is involved in online co-innovation. The subtext is that the customer has responded to the co-innovation activities in the community. The degree of participation has a positive effect on the success rate of a project [35], which depends on the coinnovation between the enterprise and the customer. In other words, the participation in online co-innovation helps to improve the understanding of roles and service procedures, thereby enhancing the knowledge and ability of the customer [36].

The degree of participation, as an indicator of enthusiasm on co-innovation, can be measured by the participation frequency and number of posts of the customer [37]. The customers frequently involved in the co-innovation process understand more about co-innovation and know how to improve the product/service. Therefore, the greater the degree of participation, the easier the perception of ease of use and usefulness. On this basis, the following hypotheses were put forward:

H2a. The degree of participation has a positive influence on perceived ease of use towards online co-innovation community.

$\mathrm{H} 2 \mathrm{~b}$. The degree of participation has a positive influence on perceived usefulness towards online co-innovation community.

\subsection{Perceived ease of use}

Being an original predictor in the TAM [10], perceive ease of use has been widely adopted to explore customer attitude and behavioral intention. It is treated as an attitude determinant by Hung et al. [38]. Sometimes, the perceived ease of use is defined as the extent to which an individual considers an IT is easy and unproblematic.

The enterprise-customer co-innovation mainly takes place on the website and apps of online co-innovation community. The customer is more likely to continue with participation, only if he/she feels that it is easier to share ideas and knowledge on the online community than report information to the enterprise, and that it is worthwhile to get involved in co-innovation. After perceiving the ease of use, the customer may be more optimistic about the next participation [39]. On this basis, the following hypotheses were put forward:

H3. Perceived ease of use has a positive influence on perceived usefulness towards online co-innovation community.

H4. Perceived ease of use has a positive influence on customer attitude to continuous participation in the online coinnovation community.

\subsection{Perceived usefulness}

The perception of usefulness is another precondition of the attitude to continuous participation. The perceived usefulness is defined as the extent to which an individual believes that the use of a system may improve his/her performance [40]. Some people demonstrated from the perspective of the perceived value which is defined as users' general assessment regarding the utility of a product or service based on the perception of what is received and what is given $[41,42]$. In the light of prior experience, a customer tends to favor continuous participation in co-innovation, if he/she trusts that joining the co-innovation community can broaden his/her knowledge of the products/services or bring other benefits. In addition, the customer may regard the online community as an efficient channel to share his/her views on the products/services. On this basis, the following hypothesis was put forward:

H5. Perceived usefulness has a positive influence on customer attitude to continuous participation in the online coinnovation community.

\subsection{Atmosphere}

The environment of co-innovation community creates a sense of perceived usefulness to the customer participating in co-innovation. Thus, many enterprises, such as Xiaomi and Starbucks, have established co-innovation websites to provide customers with impressive experiences [43]. The atmosphere of these websites makes customers feel free to participate in co-innovation. Of course, each website has a unique atmosphere, which acts as the context for the thoughts, feelings, and behaviors of customers [14].

Yadav and Varadarajan [44] revealed that the customercustomer interactions form a bustling atmosphere in the coinnovation website, and contribute to the formation of platform identity. Anastasiia [45] found that a free atmosphere in the online co-innovation community promotes the expression, thinking, and communication of customers, and boost the active participation in co-innovation. Liang et al. 
(2008) pointed that community atmosphere is a key impactor of knowledge-sharing behaviors.

Through the above analysis, the authors held that the continuous participation of customers can be promoted by a community atmosphere that is open, interesting, fair, friendly, and collaborative. The customer will opt out if the atmosphere is annoying, tense, and inactive. On this basis, the following hypothesis was put forward:

H6. Atmosphere in the co-innovation community has a positive influence on attitude to continuous participation.

Furthermore, the TAM [40] suggests that the intention for IT usage could be affected by the attitude towards the technology. This suggestion has been validated by the research on many co-innovation websites $[9,46]$. On this basis, the following hypothesis was put forward:

H7. Attitude to continuous participation has a positive influence on intention for continuous participation in the online co-innovation community.

\subsection{Questionnaire design and subjects}

This research targets Xiaomi customers who have participated in and understand co-innovation. The information of these customers was obtained from the official website of Xiaomi online co-innovation community (Xiaomi.cn).

The questionnaire was prepared by modifying the questionnaire in relevant literature [28, 32, 35, 37, 39, 47-50] as per the needs of this research. A total of 21 items in 7 constructs were designed in the questionnaire: perceived positive feedback ( 5 items), degree of participation (3 items), atmosphere (2 items), perceived ease of use (3 items), perceived usefulness ( 3 items), attitude to continuous participation (2 items), and intention for continuous participation (3 items).

During the questionnaire survey, each subject was asked to rate their agreement with each item against a 5-point Likert scale, where 1 means strongly disagree, 3 means neutrality, and 5 means strongly agree. The subjects were contacted directly based on the customer information on Xiaomi.cn.

A total of 300 questionnaires were distributed online, among which 230 were returned. After removing the incomplete ones, 205 valid questionnaires were obtained, putting the net response rate at $68.33 \%$. Among the respondents, $71.2 \%$ are male and $28.2 \%$ are female; about $60 \%$ are aged between 21 and 30. In terms of occupation, $30.2 \%$ are freelancers, $29.3 \%$ are students, $13.2 \%$ are civil servants or public workers, $12.7 \%$ are business workers, and $4.4 \%$ are self-employed. The monthly income of $34.6 \%$ is below CNY 3,000, 26.8\% between CNY 3,001 and 5,000, $22.4 \%$ between CNY 5,001 and 7,000, and $16.1 \%$ above CNY 7,000 . Table 1 is listed for details.

Table 1. The features of the respondents

\begin{tabular}{cccc}
\hline Measure & Item & Frequency & Percentage \\
\hline \multirow{2}{*}{ Gender } & Male & 146 & 71.2 \\
& Female & 59 & 28.2 \\
& $<20$ & 31 & 15.1 \\
\multirow{2}{*}{ Age } & $21-25$ & 64 & 31.2 \\
& $26-30$ & 61 & 29.8 \\
& $31-35$ & 15 & 7.3 \\
& $36-40$ & 13 & 6.3 \\
& $>40$ & 21 & 10.2 \\
Occupation & Civil servant and public worker & 27 & 13.2 \\
& Self-employed & 9 & 4.4 \\
& Freelancer & 62 & 30.2 \\
& Business worker & 26 & 12.7 \\
& Student & 60 & 29.3 \\
& Others & 21 & 10.2 \\
Monthly income (CNY) & $<3,000$ & 71 & 34.6 \\
& $3,001-5,000$ & 55 & 26.8 \\
& $5,001-7,000$ & 46 & 22.4 \\
& $>7,000$ & 33 & 16.1 \\
\hline
\end{tabular}

\section{DATA ANALYSIS}

The statistical analysis was carried out on SPSS Amos [51]. The research hypotheses were tested through the SEM. Firstly, the measurement model was examined by assessing the psychometric properties of our measures. Then, the fitness of the model was evaluated, before hypothesis test.

\subsection{Measurement model}

The validity and reliability of the constructs in our model were evaluated through confirmatory factor analysis (CFA), using the Cronbach's alpha (CA) coefficient. And Cronbach's alpha (CA) can be acceptable if it is .70 or higher [52]. To begin with, the construct reliability was verified by the CA statistic generated by SPSS. The CA of our constructs was between 0.812 and 0.936 , within the acceptable range of $\geq 0.70$. Hence, the constructs and their items in our model are highly consistent.

Next, the convergent validity of our model was tested. As shown in Table 2, the composite reliability (CR) and average variance extracted (AVE) were obtained as 0.921-0.976 and 0.504-0.779, respectively. Both indices satisfied the acceptable ranges $(\geq 0.70$ and $\geq 0.50)$. This means all constructs and their items in our model have high convergent ability.

Discriminant validity is the extent to which a measure is not a reflection of other variables. A good discriminant validity is indicated by low correlations between the measure of interest and the measures of other constructs [53]. Following the advice from Fornell and Larcker, this paper examines the discriminant validity against the rule that the square root of the AVE of each construct should be greater than its correlations 
with all other constructs. As shown in Table 3, our measures were found to have adequate discriminant validity, as each of them met the said rule.

\subsection{Structural model}

The fitness indices of our model in Table 4 show that our model has a high goodness of fit with the research data: the Chi-square $\left(\chi^{2}\right)$ /degree of freedom (df) was 2.158 , below the maximum cut-off of 5.0 [54]; the root mean square of approximation (RMSEA) was 0.075 , less than the threshold of 0.10 [55]; the normed fit index (NFI), incremental fit index (IFI), and comparative fit index (CFI) were 0.901, 0.944, and 0.943 , respectively, all greater than the suggested estimates of $0.90[56]$.
The estimated path coefficients in Table 5 indicate that perceived positive feedback has a significant effect on perceived usefulness and perceived ease of use $(\beta=0.846$, $\mathrm{p}<0.001 ; \beta=0.525, \mathrm{p}<0.01)$; The degree of participation has a significant effect on perceived ease of use $(\beta=0.364, \mathrm{p}<0.05)$, but an insignificant effect on perceived usefulness $(\beta=0.108$, $\mathrm{p}=0.454)$; Perceived ease of use has no significant effect on perceived usefulness $(\beta=0.014, \quad \mathrm{p}=0.907)$; Perceived usefulness has a significant effect on attitude to continuous participation $(\beta=0.323, \mathrm{p}<0.01)$; Perceived ease of use has no significant effect on attitude to continuous participation $(\beta=$ $0.187, \mathrm{p}=0.23$ ); Atmosphere has a significant effect on attitude to continuous participation $(\beta=0.463, \mathrm{p}<0.001)$; Attitude to continuous participation has a significant effect on the intention for continuous participation $(\beta=0.964, \mathrm{p}<0.001)$.

Table 2. The convergent validity of the constructs and their items

\begin{tabular}{|c|c|c|c|}
\hline Construct and Items & Factor loading & Mean & SD \\
\hline Perceived positive feedback (PPF) & $C A: 0.842, C R: 0.973$, & & \\
\hline I keep participating in Xiaomi co-innovation because my ideas were adopted by Xiaomi. & $A V E: 0.504$ & 3.87 & 1.028 \\
\hline I keep participating in Xiaomi co-innovation because I was rewarded by Xiaomi. & 0.660 & 3.26 & 1.227 \\
\hline $\begin{array}{l}\text { I keep participating in Xiaomi co-innovation because my posts received lots of comments } \\
\text { and relies from other users. }\end{array}$ & $\begin{array}{l}0.609 \\
0.814\end{array}$ & 3.93 & 1.010 \\
\hline $\begin{array}{c}\text { I keep participating in Xiaomi co-innovation because my posts were responded well by } \\
\text { Xiaomi. }\end{array}$ & 0.771 & 3.59 & 1.154 \\
\hline I keep participating in Xiaomi co-innovation because I gained many followers. & 0.676 & 3.28 & 1.187 \\
\hline Degree of participation (DP) & $\begin{array}{l}C A: 0.905, C R: 0.963 \\
A V E: 764\end{array}$ & & \\
\hline $\begin{array}{c}\text { I keep participating in Xiaomi co-innovation because I spent a long time participating in such } \\
\text { activities. }\end{array}$ & 0.858 & 3.59 & 1.196 \\
\hline $\begin{array}{c}\text { I keep participating in Xiaomi co-innovation because I have frequently participated in such } \\
\text { activities. }\end{array}$ & 0.897 & 3.73 & 1.059 \\
\hline I keep participating in Xiaomi co-innovation because I know lots of details about this brand. & 0.867 & 3.84 & 1.066 \\
\hline $\begin{array}{l}\text { Atmosphere (AM) } \\
\text { I keep participating in Xiaomi co-innovation because I like its innovative atmosphere. } \\
\text { I keep participating in Xiaomi co-innovation because I like the atmosphere of sharing new }\end{array}$ & $\begin{array}{l}C A: 0.878, C R: 0.921 \\
A V E: 0.779 \\
0.891\end{array}$ & 4.01 & 0.980 \\
\hline ideas and information with many users. & 0.875 & 4.11 & 0.951 \\
\hline $\begin{array}{l}\text { Perceived ease of use (PEU) } \\
\text { I keep participating in Xiaomi co-innovation because the website is easily accessible. }\end{array}$ & $\begin{array}{c}C A: 0.812, C R: 0.938 \\
A V E: 0.605 \\
0.803\end{array}$ & 4.12 & 0.932 \\
\hline $\begin{array}{l}\text { I keep participating in Xiaomi co-innovation because posting and sharing on the website is } \\
\text { simple and easy to understand. }\end{array}$ & 0.802 & 4.03 & 0.888 \\
\hline I keep participating because I know every function of the website. & 0.728 & 3.62 & 1.030 \\
\hline $\begin{array}{c}\text { Perceived usefulness (PU) } \\
\text { I keep participating in Xiaomi co-innovation because I can present my ideas and opinions to } \\
\text { Xiaomi. }\end{array}$ & $\begin{array}{l}C A: 0.849, \text { CR: } 0.938 \\
\text { AVE: } 0.656 \\
0.783\end{array}$ & 3.97 & 0.982 \\
\hline $\begin{array}{l}\text { I keep participating in Xiaomi co-innovation because I can receive new information from } \\
\text { Xiaomi and other users. }\end{array}$ & 0.824 & 4.16 & 0.964 \\
\hline $\begin{array}{c}\text { I keep participating in Xiaomi co-innovation because I can maintain a good relationship with } \\
\text { other users. }\end{array}$ & 0.823 & 4.02 & 0.957 \\
\hline $\begin{array}{l}\text { Attitude to continuous participation (ACP) } \\
\text { I think it is good and worthwhile to keep participating in Xiaomi co-innovation. } \\
\text { I think Xiaomi co-innovation always brings me great experience. }\end{array}$ & $\begin{array}{l}C A: 0.874, C R: 0.935 \\
A V E: 0.774 \\
0.886 \\
0.874\end{array}$ & $\begin{array}{l}4.05 \\
4.05\end{array}$ & $\begin{array}{l}0.966 \\
0.943\end{array}$ \\
\hline $\begin{array}{l}\text { Intention for continuous participation (CPI) } \\
\text { I intend to continue with participating in Xiaomi co-innovation. } \\
\text { I intend to increase my participation in Xiaomi co-innovation. } \\
\text { I intend to regularly participate in Xiaomi co-innovation at the current frequency. }\end{array}$ & $\begin{array}{l}C A: 0.936, \text { CR: } 0.976 \\
\text { AVE: } 0.762 \\
0.912 \\
0.829 \\
0.876\end{array}$ & $\begin{array}{l}4.08 \\
4.05 \\
4.09\end{array}$ & $\begin{array}{l}0.936 \\
0.984 \\
0.943\end{array}$ \\
\hline
\end{tabular}

Note: SD is short for standard deviation. 
Table 3. The correlations between constructs and reflective measures

\begin{tabular}{cccccccc}
\hline & PPF & DP & AM & PU & PEOU & ACP & CPI \\
\hline Perceived positive feedback (PPF) & 0.98 & & & & & & \\
Degree of participation (DP) & 0.76 & 0.91 & & & & & \\
Atmosphere (AM) & 0.65 & 0.54 & 0.95 & & & & \\
Perceived usefulness (PU) & 0.75 & 0.67 & 0.60 & 0.89 & & & \\
Perceived ease of use (PEOU) & 0.73 & 0.65 & 0.68 & 0.69 & 0.85 & & \\
Attitude to continuous participation (ACP) & 0.66 & 0.75 & 0.71 & 0.60 & 0.73 & 0.97 & \\
Continuous participation (CPI) & 0.79 & 0.73 & 0.45 & 0.54 & 0.69 & 0.69 & 0.85 \\
\hline
\end{tabular}

Table 4. The results of fitness test

\begin{tabular}{ccccccc}
\hline Fitness index & $\chi 2 / \mathrm{df}$ & AGFI & NFI & IFI & CFI & RMSEA \\
\hline Actual value & 2.158 & 0.898 & 0.901 & 0.944 & 0.943 & 0.075 \\
Reference value & $<=3$ & $>=0.8$ & $>=0.9$ & $>=0.9$ & $>=0.9$ & $<=0.8$ \\
\hline Note: AGFI is short for adjusted goodness of fit index.
\end{tabular}

Table 5. The estimated path coefficients

\begin{tabular}{ccccccccc}
\hline & & & $\beta$ & S.E. & C.R. & P & Valid hypothesis? \\
\hline H1a & Perceived positive feedback & $--->$ & Perceived usefulness & .846 & .182 & 4.562 & $* * *$ & Yes \\
H1b & Perceived positive feedback & $--->$ & Perceived ease of use & .525 & .148 & 3.137 & $* *$ & Yes \\
H2a & Degree of participation & $--->$ & Perceived ease of use & .364 & .111 & 2.280 & $*$ & Yes \\
H2b & Degree of participation & $--->$ & Perceived usefulness & .108 & .110 & .748 & .454 & No \\
H3 & Perceived ease of use & $--->$ & Perceived usefulness & .014 & .135 & .117 & .907 & No \\
H4 & Perceived usefulness & $--->$ & Attitude to continuous participation & .323 & .124 & 2.728 & $* *$ & Yes \\
H5 & Perceived ease of use & $--->$ & Attitude to continuous participation & .187 & .110 & 1.960 & 0.23 & Yes \\
H6 & Atmosphere & $--->$ & Attitude to continuous participation & .463 & .101 & 4.540 & $* * *$ & Yes \\
H7 Attitude to continuous participation & $--->$ & Continuous intention & .964 & .060 & 16.168 & $* * *$ & Yes \\
\hline Note: $* * * p<0.001, * * p<0.01, a n d * p<0.05$ & & & & & & & &
\end{tabular}

\section{DICUSSION AND CONCLUSIONS}

This paper mainly aims to explain customer continuous participation in an online co-innovation community. The explanatory power of each construct in our model was measured by squared multiple correlations (R2) in Figure 4. It is clear that prior experience, including perceived positive feedback and degree of participation, and perceived ease of use accounted for $91 \%$ of the variance in perceived usefulness, and $74 \%$ of that in perceived use of use. Together, atmosphere, perceived usefulness, and perceived ease of use explained $83 \%$ of the variance in attitude to continuous participation. Moreover, attitude to continuous participation explained 93\% of the variance in intention for continuous participation.

As shown in Table 3, perceived usefulness and perceived ease of use are affected by perceived positive feedback. From the perspective of the TAM, our findings support the idea that perceived positive feedback has a significant impact on perceived usefulness and perceived ease of use, thus validating hypotheses H1a and H1b. Therefore, the customers will be satisfied with the online co-innovation community, when their efforts receive a favorable reaction from other active members and the enterprise. In other words, a customer participating in online co-innovation will perceive greater practical value of the participation, if more positive feedbacks are received for the participation.

In the dimension of prior experience, the degree of participation only has a significant effect on perceived ease of use, but not on perceived usefulness. This means the degree of participation in the online co-innovation community only makes customers more accustomed to the usage of the system, failing to increase their value recognition. Hence, the customer participation in online co-innovation can be better improved by the positive feedback or encouragement from the other customers and the enterprise, than by the degree of participation.

Moreover, as stated in Hypotheses 3, perceived ease of use does not have a significant effect on perceived usefulness. This reflects a unique feature of the online co-innovation community: the ease to use the website does not necessarily elevate the intention of customers to continue with participation. This finding is consistent with previous research on TAM [57].

Furthermore, both perceived usefulness and perceived ease of use have a positive impact on attitude to continuous participation, supporting $\mathrm{H} 4$ and H5. Note that the impact from perceived usefulness on attitude is stronger than that from perceived ease of use. The result indicates that the attitude of a customer to continuous participation in the online coinnovation community depends on the benefit of participation. The customer may attach more importance to the participation value and the response to ideas submitted, than to the ease of accessing and using the co-innovation website. Thus, the value of participation should be considered a key driver of continuous intention.

In addition, it was found that the atmosphere has a significant and even stronger effect on attitude to continuous participation than perceived usefulness, and attitude to continuous participation also has a significant impact on continuous intention. The above findings imply that a customer is more satisfied with the usefulness or benefit from participation than the ease of participation. As a result, the coinnovation community should pay attention to the community atmosphere, and the positive interactions between customers, and between customer and the enterprise. 


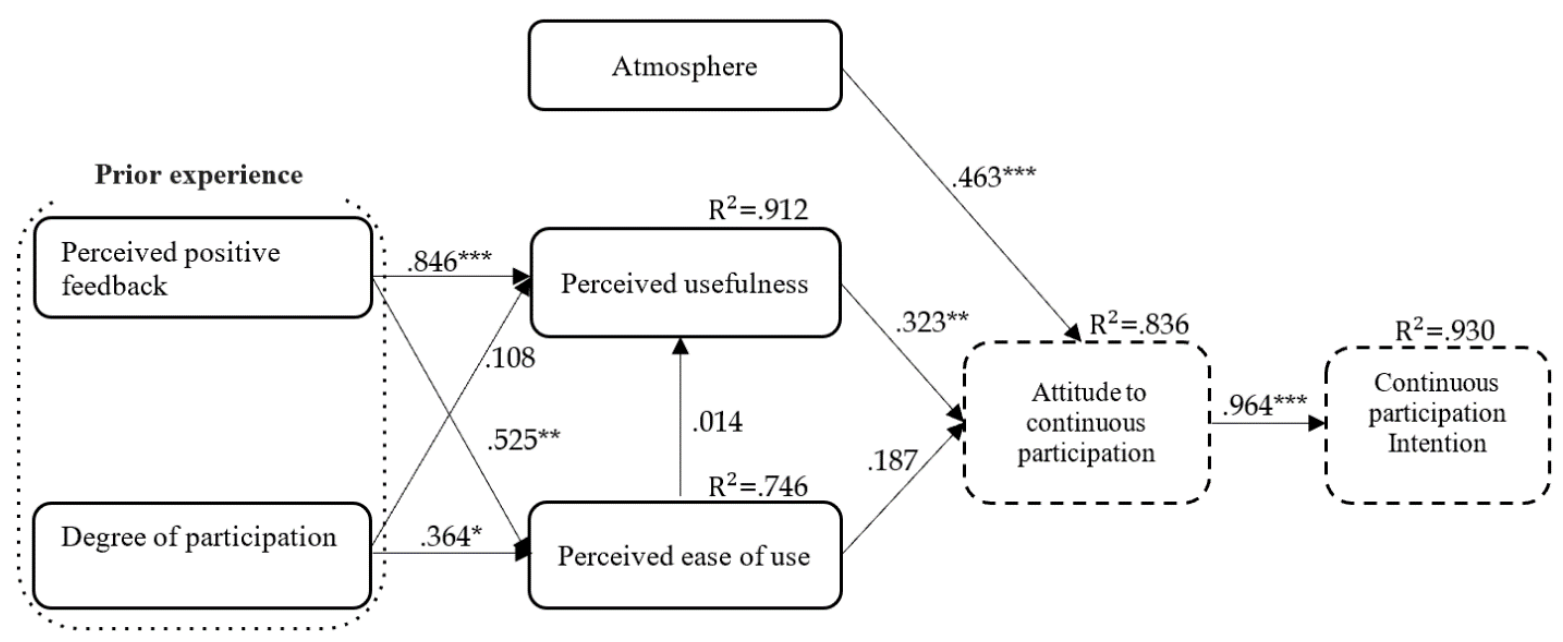

Figure 4. Result of the structured model

For the sustainability of the online co-innovation community, the enterprise needs to systematically improve the perceived positive feedback of customers, e.g. building a fair and attractive reward system and a warm and quick response mechanism. It is also important to create an atmosphere that is open, interesting, fair, and full of enthusiasm. Suitable rewards and feedbacks can make the co-innovation tasks more interesting to customers, boosting their continuous participation.

Of course, there are several limitations of this research. For instance, our respondents are all customers of Xiaomi, and our findings might not be directly applied to other online coinnovation communities. To reduce the bias in sample selection, the future research should cover more online coinnovation communities, making the results more reliable. Besides, the credibility of the established model needs to be further improved by considering more constructs like brand passion, brand knowledge, and self-efficacy. Finally, the demographic features or individual diversity, such as occupation, income, age and gender, should be included in the model and subject to further discussion.

\section{ACKNOWLEDGMENT}

This work is supported by Humanity and Social Science Planning Foundation of Ministry of Education of China under Grant 20YJA630020. And partly supported by the CSC scholarship (Grant No.: 20180776005).

\section{REFERENCES}

[1] Ma, J., Lu, Y., Gupta, S. (2019). User innovation evaluation: Empirical evidence from an online game community. Decision Support Systems, 117: 113-123. https://doi.org/10.1016/j.dss.2018.11.003

[2] Sun, Y., Fang, Y., Lim, K.H. (2012). Understanding sustained participation in transactional virtual communities. Decision Support Systems, 53(1): 12-22. https://doi.org/10.1016/j.dss.2011.10.006

[3] Fang, C., Zhang, J. (2019). Users' continued participation behavior in social Q\&A communities: A motivation perspective. Computers in Human Behavior, 92: 87-109. https://doi.org/10.1016/j.chb.2018.10.036
[4] Wang, Y., Ma, S.S., Li, D. (2015). Customer participation in virtual brand communities: The selfconstrual perspective. Information \& Management, 52(5): 577-587. https://doi.org/10.1016/j.im.2015.04.003

[5] Shulga, L.V., Busser, J.A., Bai, B. (2018). Factors affecting willingness to participate in consumer generated advertisement. International Journal of Hospitality Management, 74: 214-223. https://doi.org/10.1016/j.ijhm.2018.05.004

[6] Antikainen, M., Mäkipää, M., Ahonen, M. (2010). Motivating and supporting collaboration in open innovation. European Journal of Innovation Management, $13(1)$ : 100-119. https://doi.org/10.1108/14601061011013258

[7] Bettoni, M.C., Andenmatten, S., Mathieu, R. (2007). Knowledge cooperation in online communities: A duality of participation and cultivation. The Electronic Journal of Knowledge Management, 5(1): 1-6.

[8] Paulini, M., Maher, M.L., Murty, P. (2014). Motivating participation in online innovation communities. International Journal of Web Based Communities, 10(1): 94-114. https://doi.org/10.1504/IJWBC.2014.058388

[9] Cheng, Y.M., Lou, S.J., Kuo, S.H., Shih, R.C. (2013). Investigating elementary school students' technology acceptance by applying digital game-based learning to environmental education. Australasian Journal of Educational Technology, 29(1): 96-110. https://doi.org/10.14742/ajet.65

[10] Von Krogh, G., Spaeth, S., Lakhani, K.R. (2003). Community, joining, and specialization in open source soft-ware innovation: A case study. Research Policy, 32(7): 1217-1241. https://doi.org/10.1016/S00487333(03)00050-7

[11] Davis, F.D. (1989). Perceived usefulness, perceived ease of use, and user acceptance of information technology. MIS Quarterly, 319-340. http://doi.org/10.2307/249008

[12] Hu, P.J., Chau, P.Y., Sheng, O.R.L., Tam, K.Y. (1999). Examining the technology acceptance model using physician acceptance of telemedicine technology. Journal of Management Information Systems, 16(2): 91112. https://doi.org/10.1080/07421222.1999.11518247

[13] Legris, P., Ingham, J., Collerette, P. (2003). Why do people use information technology? A critical review of the technology acceptance model. Information \& Management, 40(3):

191-204. 
https://doi.org/10.1016/S0378-7206(01)00143-4

[14] Bock, G.W., Zmud, R.W., Kim, Y.G., Lee, J.N. (2005). Behavioral intention formation in knowledge sharing: Examining the roles of extrinsic motivators, socialpsychological forces, and organizational climate. MIS Quarterly, 87-111. https://doi.org/10.2307/25148669

[15] Ofori, K.S., Larbi-Siaw, O., Fianu, E., Gladjah, R.E., Boateng, E.O.Y. (2016). Factors influencing the continuance use of mobile social media: The effect of privacy concerns. Journal of Cyber Security and Mobility, 4(3): 105-124. https://doi.org/10.13052/jcsm22451439.426

[16] Dholakia, U.M., Bagozzi, R.P., Pearo, L.K. (2004). A social influence model of consumer participation in network-and small-group-based virtual communities. International Journal of Research in Marketing, 21(3): 241-263. https://doi.org/10.1016/j.ijresmar.2003.12.004

[17] Eric, F. Robert, W., Keneth, R. (2008). Influence of customer participation on creating and sharing of new product value. Academy of Marketing Science, 36: 322336. http://doi.org/ 10.1007/s11747-007-0082-9

[18] Bateman, P.J., Gray, P.H., Butler, B.S. (2011). Research note - the impact of community commitment on participation in online communities. Information Systems Research, 22(4): 841-854. https://doi.org/10.1287/isre.1090.0265

[19] Wasko, M.M., Faraj, S. (2005). Why should I share? Examining social capital and knowledge contribution in electronic networks of practice. MIS Quarterly, 35-57. http://doi.org/10.2307/25148667

[20] Ridings, C.M., Gefen, D. (2004). Virtual community attraction: Why people hang out online. Journal of Computer-Mediated Communication, 10(1): JCMC10110. https://doi.org/10.1111/j.10836101.2004.tb00229.x

[21] Bhattacherjee, A. (2001). Understanding information systems continuance: An expectation-confirmation model. MIS Quarterly, 351-370. http://doi.org/10.2307/3250921

[22] Oliver, R.L. (1977). Effect of expectation and disconfirmation on post exposure product evaluations: An alternative interpretation. Journal of Applied Psychology, 62(4): 480. https://doi.org/10.1037/00219010.62.4.480

[23] Oliver, R.L. (1993). Cognitive, affective, and attribute bases of the satisfaction response. Journal of Consumer Research, 20(3): 418-430 https://doi.org/10.1086/209358

[24] Liang, T.P., Liu, C.C., Wu, C.H. (2008). Can social exchange theory explain individual knowledge-sharing behavior? A meta-analysis. ICIS 2008 Proceedings, 171. https://aisel.aisnet.org/icis2008/171

[25] Chai, S., Das, S., Rao, H.R. (2011). Factors affecting bloggers' knowledge sharing: An investigation across gender. Journal of Management Information Systems, 28(3): 309-342. https://doi.org/10.2753/MIS07421222280309

[26] Usoro, A., Sharratt, M.W., Tsui, E., Shekhar, S. (2007). Trust as an antecedent to knowledge sharing in virtual communities of practice. Knowledge Management Research \& Practice, 5(3): 199-212. https://doi.org/10.1057/palgrave.kmrp.8500143

[27] Lu, H.P., Hsiao, K.L. (2007). Understanding intention to continuously share information on weblogs. Internet
Research. https://doi.org/10.1108/10662240710828030

[28] Zhang, C., Hahn, J., De, P. (2013). Research notecontinued participation in online innovation communities: Does community response matter equally for everyone? Information Systems Research, 24(4): 1112-1130. https://doi.org/10.1287/isre.2013.0485

[29] Fazio, R.H., Zanna, M.P. (1978). Attitudinal qualities relating to the strength of the attitude-behavior relationship. Journal of Experimental Social Psychology, 14(4): 398-408. https://doi.org/10.1016/0022-1031(78)90035-5

[30] Limayem, M., Cheung, C.M.K. (2011). Predicting the continued use of internet-based learning technologies: The role of habit. Behavior \& Information Technology, $30(1)$ : 91-99. http://doi.org/10.1080/0144929X.2010.490956

[31] Chiu, C.K., Lin, C.P., Chen, K.J., Liu, C.M., Ma, H.C. (2019). Modeling continuance intention towards Mobile Travel Service System (MTSS): A theoretical perspective of motivation and dependency. Review of Managerial Science, 13(4): 749-769. https://doi.org/10.1007/s11846-017-0257-9

[32] Faullant, R., Dolfus, G. (2017). Everything community? Destructive processes in communities of crowdsourcing competitions. Business Process Management Journal, https://doi.org/10.1108/BPMJ-10-2016-0206

[33] Rice, R.E., Grant, A.E., Schmitz, J., Torobin, J. (1990). Individual and network influences on the adoption and perceived outcomes of electronic messaging. Social Networks, 12(1): 27-55. https://doi.org/10.1016/03788733(90)90021-Z

[34] Lu, J. (2014). Are personal innovativeness and social influence critical to continue with mobile commerce. Internet Research. https://doi.org/10.1108/IntR-05-20120100

[35] Zheng, Q., Guo, W., An, W., Wang, L., Liang, R. (2018). Factors facilitating user projects success in co-innovation communities. Kybernetes. https://doi.org/10.1108/K-012017-0012

[36] Dong, B., Evans, K.R., Zou, S. (2008). The effects of customer participation in co-created service recovery. Journal of the Academy of Marketing Science, 36(1): 123-137. http://doi.org/ 10.1007/s11747-007-0059-8

[37] Zhang, T.C., Kandampully, J., Bilgihan, A. (2015). Motivations for customer engagement in online coinnovation communities (OCCs). Journal of Hospitality and Tourism Technology, 6(3): 311. https://doi.org/10.1108/JHTT-10-2014-0062

[38] Hung, S.Y., Lai, H.M., Chou, Y.C. (2015). Knowledgesharing intention in professional virtual communities: A comparison between posters and lurkers. Journal of the Association for Information Science and Technology, 66(12): 2494-2510. https://doi.org/10.1002/asi.23339

[39] Cheung, M.F., To, W.M. (2016). Service co-creation in social media: An extension of the theory of planned behavior. Computers in Human Behavior, 65: 260-266. https://doi.org/10.1016/j.chb.2016.08.031

[40] Davis, F.D., Bagozzi, R.P., Warshaw, P.R. (1989). User acceptance of computer technology: A comparison of two theoretical models. Management Science, 35(8): 982-1003. https://doi.org/10.1287/mnsc.35.8.982

[41] Zeithaml, V.A. (1988). Consumer perceptions of price, quality, and value: A means-end model and synthesis of evidence. Journal of Marketing, 52(3): 2-22. https://doi.org/10.1177/002224298805200302 
[42] Al-Debei, M.M., Al-Lozi, E., Papazafeiropoulou, A. (2013). Why people keep coming back to Facebook: Explaining and predicting continuance participation from an extended theory of planned behavior perspective. Decision Support Systems, 55(1): 43-54. https://doi.org/10.1016/j.dss.2012.12.032

[43] Von Krogh, G., Spaeth, S., Lakhani, K.R. (2003). Community, joining, and specialization in open source soft-ware innovation: A case study. Research Policy, 32(7): 1217-1241. https://doi.org/10.1016/S00487333(03)00050-7

[44] Yadav, M.S., Varadarajan, R. (2005). Interactivity in the electronic marketplace: An exposition of the concept and implications for research. Journal of the Academy of Marketing Science, 33(4): 585-603. https://doi.org/10.1177/0092070305278487

[45] Anastasiia A.N. (2018). The influence of consumer motivations on online brand community engagement. 2018 Global Marketing Conference at Tokyo Proceedings, 942-948 http://doi.org.10.15444/GMC2018.08.05.06

[46] Gu, X., Zhu, Y., Guo, X. (2013). Meeting the "digital natives": Understanding the acceptance of technology in classrooms. Journal of Educational Technology \& Society, 16(1): 392-402. http://doi.org/10.2307/jeductechsoci.16.1.392

[47] Taylor, S., Todd, P.A. (1995). Understanding information technology usage: A test of competing models. Information Systems Research, 6(2): 144-176. https://doi.org/10.1287/isre.6.2.144

[48] Yap, S.F., Gaur, S.S. (2016). Integrating functional, social, and psychological determinants to explain online social networking usage. Behavior \& Information Technology, 35(3): 166-183. https://doi.org/10.1080/0144929X.2015.1035336

[49] Fernandes, T., Remelhe, P. (2016). How to engage customers in co-creation: customers' motivations for collaborative innovation. Journal of Strategic Marketing, 24(3-4): 311-326. https://doi.org/10.1080/0965254X.2015.1095220

[50] Zeithaml, V.A. (1988). Consumer perceptions of price, quality, and value: A means-end model and synthesis of evidence. Journal of Marketing, 52(3): 2-22. https://doi.org/10.1177/002224298805200302

[51] Mouakket, S. (2015). Factors influencing continuance intention to use social network sites: The Facebook case. Computers in Human Behavior, 53: 102-110. https://doi.org/10.1016/j.chb.2015.06.045

[52] Fornell, C., Yi, Y. (1992). Assumptions of the two-step approach to latent variable modeling. Sociological Methods \& Research, 20(1): 291-320. https://doi.org/10.1177/0049124192020003001

[53] Fornell, C., Larcker, D.F. (1981). Evaluating structural equation models with unobservable variables and measurement error. Journal of Marketing Research, 18(1): $39-50$. https://doi.org/10.1177/002224378101800104

[54] Bentler, P.M., Bonett, D.G. (1980). Significance tests and goodness of fit in the analysis of covariance structures. Psychological Bulletin, 88(3): 588. https://doi.org/10.1037/0033-2909.88.3.588

[55] Anderson, J.C., Gerbing, D.W. (1988). Structural equation modeling in practice: $\mathrm{A}$ review and recommended two-step approach. Psychological Bulletin, 103(3): $411 . \quad$ http://doi.org/10.1037/00332909.103.3.411

[56] Hoelter, J.W. (1983). The analysis of covariance structures: Goodness-of-fit indices. Sociological Methods and Research, 11: 325-344. http://doi.org/10.1177/0049124183011003003

[57] Cheng, Y.M. (2018). What drives cloud ERP continuance? An integrated view. Journal of Enterprise Information Management. https://doi.org/10.1108/JEIM02-2018-0043 